\title{
Sleeping to fuel the immune system: mammalian sleep and resistance to parasites Mark R Opp
}

Address: Departments of Anesthesiology and Molecular \& Integrative Physiology, University of Michigan Medical School, Ann Arbor, MI, USA Email: Mark R Opp - mopp@umich.edu

Published: 9 January 2009

BMC Evolutionary Biology 2009, 9:8 doi:10.1 186//47|-2|48-9-8

This article is available from: http://www.biomedcentral.com/I47I-2/48/9/8

(c) 2009 Opp; licensee BioMed Central Ltd.

This is an Open Access article distributed under the terms of the Creative Commons Attribution License (http://creativecommons.org/licenses/by/2.0), which permits unrestricted use, distribution, and reproduction in any medium, provided the original work is properly cited.

Received: 23 October 2008

Accepted: 9 January 2009

\begin{abstract}
Sleep is an enigma. Why animals forgo eating and reproducing, while potentially increasing their risk of predation remains unknown. Although some may question whether all animals sleep, it is clear that all living organisms possess defenses against attack by pathogens. Immune responses of humans and animals are impaired by sleep loss, and responses to immune challenge include altered sleep. Thus, sleep is hypothesized to be a component of the acute phase response to infection and to function in host defense. Examining phylogenetic relationships among sleep parameters, components of the mammalian immune system and resistance to infection may provide insight into the evolution of sleep and lead to a greater appreciation for the role of sleep in host defense.
\end{abstract}

Sleep is perhaps the greatest enigma in all of biology. Although there have been numerous hypotheses, the question as to the function of sleep remains unanswered. Sleep states are well characterized in mammals and birds, and there is convincing evidence for sleep in animals of "lower" phyla, including invertebrates [1]. Because many characteristics of sleep differ quite dramatically across phyla $[2,3]$, it seems that the lowest common denominator of a core function(s) for sleep must exist at the cellular level $[4,5]$.

Although we may lack an unequivocal functional explanation for sleep, the same is not true for the immune system. Quite simply, the function of the immune system is to keep the organism alive in the face of constant attack by pathogens. The physical and biochemical components of the immune system are integrated into a complex network that is, in many respects, analogous to the networks of cells and transmitter substances that compose the central nervous system. Like sleep, the immune system is phylogenetically ancient. Invertebrates exhibit inflammatory responses to invading pathogens that are functionally equivalent to those of vertebrates [6]. The ability of invertebrates to effectively defend themselves against pathogens is evidenced by their nearly 1 billion years of evolution and the fact they comprise about $95 \%$ of the 2 million extant animal species.

The relationship between sleep and the immune system has long been known, but only recently have these interactions been systematically investigated. Investigators have generally used two approaches. In one, human volunteers or laboratory animals are sleep deprived and effects on selected immune parameters determined. The other uses laboratory animals (and in some cases humans) that have been infected with pathogens or challenged with immunomodulators. It is now possible to state that sleep loss alters immune function and that immune challenge alters sleep. What are the mediators of these bi-directional interactions between sleep and the immune system? 
Cytokines are the major orchestrators of host defense. Almost twenty of these proteins have been studied to determine effects on sleep. Of these, interleukin-1 (IL-1) and tumor necrosis factor (TNF) have been demonstrated to play a role in the regulation of normal mammalian non rapid eye movement sleep. Data derived from electrophysiological, biochemical and molecular genetic studies demonstrate that antagonizing the IL-1 or the TNF systems reduces spontaneous non rapid eye movement sleep of freely behaving, healthy animals $[7,8]$. Furthermore, when faced with antigenic challenge, activity of the IL-1 and TNF systems increases and so does non rapid eye movement sleep.

Because sleep loss impairs immune function and immune challenge alters sleep it has been hypothesized that sleep may be considered a component of the acute phase response to infection [9] and functions in host defense [10]. If indeed this is the case, there should be evidence that evolution has favored organisms that optimized the relative investments in sleep and host defense. In this issue, Preston and colleagues [11] ask whether correlations exist between sleep times of mammals and numbers (and types) of white blood cells. Because white blood cells are central to immune responses, these authors used counts as a measure of species investment in the immune system. Their results indicate that across 26 mammalian species those with more total sleep have higher numbers of white blood cells. This positive association of total sleep time with numbers of cells was revealed in four out of the five white blood cell types. Such correlations do not exist for red blood cells, which served as controls because they are derived from the same hematopoietic precursors as white blood cells but have no direct immunological function.

An increase in the number of white blood cells in species that sleep more suggests they should be more immunocompetent. Are there indicators that the association between increased sleep time and white blood cell counts is adaptive? Analysis of sleep times of 12 mammalian species for which data also are available with respect to parasitic load indicates that a 10 hour increase in sleep time is associated with a 24 -fold decrease in parasitism. On the basis of this intriguing relationship, Preston et al., [11] conclude that species that have evolved longer sleep times have been able to effectively increase their investment in host defense and reduce the impact of parasites.

Results of this study demonstrate for the first time a correlation between phylogenetic sleep parameters and measures of immune investment. Preston et al., hypothesize that sleep fuels the immune system and they demonstrate increased resistance to parasites in mammalian species that sleep more. But how is resistance to parasites con- ferred? And what does parasite resistance of mammals suggest about possible evolutionary relationships between sleep and the immune system?

Although physical barriers are the first line of defense against pathogens, increased numbers of white blood cells suggest that what may be important in combating parasites is not just "keeping them out", but the response that is mounted once the pathogen invades and is detected by the host [12-14]. Is it possible that it was host defense responses to antigenic challenge from multiple microbial pathogens that selected for greater numbers of white blood cells and subsequent evolution of sleep rather than increased sleep time leading to greater immunocompetence?

Although they have evolved independently for more than 500 million years, most models postulate a monophyletic origin for vertebrate and invertebrate immune systems that predates the bifurcation in their evolution. For example, IL-1-, IL-6-, TNF-, and transforming growth factor (TGF)- $\beta$-like molecules exist in annelids, mollusks, and arthropods (all protostomes), and in echinoderms and protochordates (deuterostomes). Not only do these cytokines exist in invertebrates, they do so in neural tissue [15-18]. The protostome nematode Caenorhabditis elegans exhibits a sleep-like state during larval-stage transitions called lethargus [19]. The only gene thus far implicated in sleep-like behavior in C. elegans is egl-4, which signals through the Decapentaplegic, BMP-like/transforming growth factor- $\beta$ pathway. Although we do not know whether activation of innate immune defenses alters the lethargus sleep-like state in C. elegans, loss of function of Decapentaplegic, BMP-like-1 does increase sensitivity to infection. Several mutant lines of the deuterostome insect Drosophila exhibit short or long sleep [1,20-22], and sleepand wake-related genes have been identified [23]. Expression profiling demonstrates that about 400 Drosophila genes are modulated during microbial infection, including the gene for the NF-kB-like transcription factor relish. $\mathrm{NF}-\kappa \mathrm{B}$ is critical in host defense due to its role in cytokine transcription and, as in rodents, flies that lack relish sleep less, and relish increases during sleep deprivation [24].

Cytokines directly alter properties of neurons in the mammalian brain [25-27], including those in regions involved in the regulation of sleep [28-32]. Although we do not yet know those neural circuits involved in sleep of invertebrates, discharge rates of invertebrate neurons are altered during inflammation or in response to cytokines [33,34]. Responses to antigenic challenge, independent of restactivity cycles or metabolic demands, could have led to selection of a variety of processes in which ancestral organisms must have engaged. It is not possible to know if responses to antigenic challenge through the course of 
evolution shaped complex behavior of animals in modern phyla. In theory however, such responses could have driven the evolution of many behaviors and physiological processes in which cytokines are now implicated, including sleep, thermoregulation, feeding, and locomotion. The study by Preston et al., indicates that sleep - immune interactions may also be viewed within the context of phylogeny, thus providing additional clues in the search for core function(s) of sleep.

\section{Acknowledgements}

The author is funded by grants from the National Institutes of Health MH64843, HL080972, and GM067I89.

\section{References}

I. Zimmerman JE, Naidoo N, Raizen DM, Pack Al: Conservation of sleep: insights from non-mammalian model systems. Trends Neurosci 2008, 3 I:37I-376.

2. Capellini I, Barton RA, McNamara P, Preston BT, Nunn CL: Phylogenetic analysis of the ecology and evolution of mammalian sleep. Evolution 2008, 62: I764-1776.

3. Allada R, Siegel JM: Unearthing the phylogenetic roots of sleep. Curr Biol 2008, 18:R670-R679.

4. Tononi G, Cirelli C: Sleep function and synaptic homeostasis. Sleep Med Rev 2006, 10:49-62.

5. Krueger JM: A neuronal group theory of sleep function. J Sleep Res 1993, 2:63-69

6. Loker ES, Adema CM, Zhang SM, Kepler TB: Invertebrate immune systems - not homogeneous, not simple, not well understood. Immunol Rev 2004, I 98:10-24

7. Opp MR: Cytokines and sleep. Sleep Med Rev 2005, 9:355-364.

8. Obal F Jr, Krueger JM: Biochemical regulation of non-rapid-eyemovement sleep. Front Biosci 2003, 8:d520-d550.

9. Krueger JM, Majde JA: Sleep as a host defense: its regulation by microbial products and cytokines. Clin Immunol Immunopatho 1990, 57:188-199.

10. Toth LA, Tolley EA, Krueger JM: Sleep as a prognostic indicator during infectious disease in rabbits. Proc Soc Exp Biol Med 1993 , 203:179-192.

II. Preston BT, Capellini I, McNamara P, Barton RA, Nunn CL: Parasite resistance and the adaptive significance of sleep. $B M C$ Evolutionay Biology 2009, 9:7.

12. Zhou P, Li E, Zhu N, Robertson J, Nash T, Singer SM: Role of interleukin-6 in the control of acute and chronic Giardia lamblia infections in mice. Infect Immun 2003, 71:1566-I568.

13. Zhou P, Li E, Shea-Donohue T, Singer SM: Tumour necrosis factor alpha contributes to protection against Giardia lamblia infection in mice. Parasite Immunol 2007, 29:367-374.

14. Bienz M, Dai WJ, Welle M, Gottstein B, Muller N: Interleukin-6deficient mice are highly susceptible to Giardia lamblia infection but exhibit normal intestinal immunoglobulin $A$ responses against the parasite. Infect Immun 2003, 7I:1569-1573.

15. Ottaviani E, Franchini A, Franceschi C: Pro-opiomelanocortinderived peptides, cytokines, and nitric oxide in immune responses and stress: an evolutionary approach. Int Rev Cytol 1997, I 70:79-141.

16. Paemen LR, Porchet-Hennere E, Masson M, Leung MK, Hughes TK Jr, Stefano GB: Glial localization of interleukin-I alpha in invertebrate ganglia. Cell Mol Neurobiol 1992, I 2:463-472.

17. Sonetti D, Ottaviani E, Bianchi F, Rodriguez M, Stefano ML, Scharrer $B$, et al.: Microglia in invertebrate ganglia. Proc Natl Acad Sci USA 1994, $91: 9180-9184$

18. Stefano GB, Smith EM, Hughes TK: Opioid induction of immunoreactive interleukin- $I$ in Mytilus edulis and human immunocytes: an interleukin-I-like substance in invertebrate neural tissue. I Neuroimmunol 1991, 32:29-34.

19. Raizen DM, Zimmerman JE, Maycock MH, Ta UD, You YJ, Sundaram $\mathrm{MV}$, et al:: Lethargus is a Caenorhabditis elegans sleep-like state. Nature 2008, 45 I:569-572.
20. Hendricks JC, Finn SM, Panckeri KA, Chavkin J, Williams JA, Sehgal A, et al:: Rest in Drosophila is a sleep-like state. Neuron 2000, 25: $129-138$.

2I. Shaw PJ, Cirelli C, Greenspan RJ, Tononi G: Correlates of sleep and waking in Drosophila melanogaster. Science 2000, 287:1834-1837.

22. Sehgal A, Joiner W, Crocker A, Koh K, Sathyanarayanan S, Fang Y, et al:: Molecular Analysis of Sleep: Wake Cycles in Drosophila. Cold Spring Harb Symp Quant Biol 2007, 72:557-564.

23. Cirelli C, Bushey D: Sleep and wakefulness in Drosophila melanogaster. Ann N Y Acad Sci 2008, I I 29:323-329.

24. Williams JA, Sathyanarayanan S, Hendricks JC, Sehgal A: Interaction between sleep and the immune response in Drosophila: a role for the NFkappaB relish. Sleep 2007, 30:389-400.

25. Shibata M, Blatteis CM: Differential effects of cytokines on thermosensitive neurons in guinea pig preoptic area slices. $A m$ Physiol I99I, 26I:RI096-RII03.

26. Kenney MJ, Blecha F, Fels RJ, Morgan DA: Altered frequency responses of sympathetic nerve discharge bursts after ILI beta and mild hypothermia. I Appl Physiol 2002, 93:280-288.

27. Vasilenko VY, Petruchuk TA, Gourine VN, Pierau FK: InterleukinI beta reduces temperature sensitivity but elevates thermal thresholds in different populations of warm-sensitive hypothalamic neurons in rat brain slices. Neurosci Lett 2000 , 292:207-210.

28. Alam MN, McGinty D, Bashir T, kumar S, Imeri L, Opp MR, et al: Interleukin- I $\beta$ modulates state-dependent discharge activity of preoptic area and basal forebrain neurons: role in sleep regulation. Eur J Neurosci 2004, 20:207-216.

29. Brambilla D, Franciosi S, Opp MR, Imeri L: Interleukin-I inhibits firing of serotonergic neurons in the dorsal raphe nucleus and enhances GABAergic inhibitory post-synaptic potentials. Eur J Neurosci 2007, 26: I862-1869.

30. De A, Churchill L, Obal F Jr, Simasko SM, Krueger JM: GHRH and ILIbeta increase cytoplasmic $\mathrm{Ca}(2+)$ levels in cultured hypothalamic GABAergic neurons. Brain Res 2002, 949:209-2। 2

31. De A, Krueger JM, Simasko SM: Tumor necrosis factor alpha increases cytosolic calcium responses to AMPA and $\mathrm{KCl}$ in primary cultures of rat hippocampal neurons. Brain Res 2003, 981: $133-142$

32. Manfridi A, Brambilla D, Bianchi S, Mariotti M, Opp MR, Imeri L: Interleukin-I $\beta$ enhances non-rapid eye movement sleep when microinjected into the dorsal raphe nucleus and inhibits serotonergic neurons in vitro. Eur J Neurosci 2003, 18:104I-1049.

33. Mimura Y, Gotow T, Nishi T, Osame M: Mechanisms of hyperpolarization induced by two cytokines, hTNF alpha and hIL-I alpha in neurons of the mollusc, Onchidium. Brain Res 1994, 653:112-118.

34. Farr M, Mathews J, Zhu DF, Ambron RT: Inflammation causes a long-term hyperexcitability in the nociceptive sensory neurons of Aplysia. Learn Mem 1999, 6:331-340.

Publish with Bio Med Central and every scientist can read your work free of charge

"BioMed Central will be the most significant development for disseminating the results of biomedical research in our lifetime. "

Sir Paul Nurse, Cancer Research UK

Your research papers will be:

- available free of charge to the entire biomedical community

- peer reviewed and published immediately upon acceptance

- cited in PubMed and archived on PubMed Central

- yours - you keep the copyright 